\title{
Pengaruh Kecerdasan Emosional dan Penguasaan Struktur Kalimat terhadap Kemampuan Menulis Eksposisi
}

\author{
Wiwin Sri Ningsih ${ }^{1)}$ \\ Universitas Indraprasta PGRI \\ Jalan Nangka No. 58 C/TB. Simatupang, Tanjung Barat, Jakarta Selatan 12530 \\ Sumaryati Tjitro Sumarto ${ }^{2)}$ \\ Universitas Indraprasta PGRI \\ Jalan Nangka No. 58 C/TB. Simatupang, Tanjung Barat, Jakarta Selatan 12530
}

wiwinsri32@gmail.com ${ }^{1)}$

\begin{abstract}
This study aims to determine the direct and indirect effects of emotional intelligence and mastery of sentence structure on the ability to write exposition. The study was conducted by survey method and using the Multi Stage Sampling technique. The instruments used were questionnaires and exposition writing test results. Data was processed with the help of SPSS 20, and Microsoft Excel and analyzed using the path analysis method. Based on the results of the analysis that has been done, it is concluded that (1) there is a significant direct effect of emotional intelligence a direct influence on the mastery of sentence structure; (2) there is a significant direct effect on emotional intelligence on the ability to write exposition; (3) there is a significant direct effect on the mastery of sentence structure on the ability to write exposition; and (4) there is a significant indirect effect of emotional intelligence on the ability to write exposition through mastery of sentence structure.
\end{abstract}

Keywords: emotional intelligence, sentence structure, writing exposition.

\begin{abstract}
Abstrak
Tujuan penelitian ini adalah untuk menganalisis dan menguji kebenaran hipotesis mengenai pengaruh kecerdasan emosional dan penguasaan struktur kalimat terhadap kemampuan menulis eksposisi. Hipotesis penelitian yang diuji meliputi (1) pengaruh kecerdasan emosional dan penguasaan struktur kalimat secara bersama-sama terhadap kemampuan menulis eksposisi; (2) pengaruh kecerdasan emosional terhadap kemampuan menulis eksposisi; (2) pengaruh penguasaan struktur kalimat terhadap kemampuan menulis eksposisi. Penelitian dilakukan dengan metode survei dan menggunakan teknik Multi Stage Sampling. Instrumen yang digunakan adalah angket dan hasil tes menulis eksposisi. Data diolah dengan bantuan SPSS 20, dan microsoft excel dan dianalisis dengan menggunakan metode regresi. Berdasarkan hasil analisis yang telah dilakukan, diperoleh simpulan bahwa (1) terdapat pengaruh yang signifikan kecerdasan emosional dan penguasaan struktur kalimat secara bersama-sama terhadap kemampuan menulis eksposisi; (2) terdapat pengaruh yang signifikan kecerdasan emosional terhadap kemampuan menulis eksposisi; (3) terdapat pengaruh yang signifikan penguasaan struktur kalimat terhadap kemampuan menulis eksposisi.
\end{abstract}

Kata Kunci: kecerdasan emosional, struktur kalimat, menulis eksposisi 


\section{PENDAHULUAN}

Pendidikan sebagai cara yang tepat dalam membentuk sumber daya manusia yang berkualitas untuk mendukung tercapainya tujuan pembangunan nasional. Melalui pendidikan, manusia mendapatkan pengetahuan, keterampilan, nilai dan sikap sehingga dapat berpikir lebih sistematis, rasional, dan kritis terhadap permasalahan yang dihadapi. Pendidikan adalah usaha sadar dan terencana untuk mewujudkan suasana belajar dan proses pembelajaran agar peserta didik secara aktif mengembangkan potensi dirinya untuk memiliki kekuatan spiritual keagamaan, pengendalian diri, kepribadian, kecerdasan, akhlak mulia, serta keterampilan yang diperlukan dirinya, masyarakat, bangsa, dan negara. Proses pembelajaran berkualitas sangat ditentukan oleh kualitas guru, sebagai tenaga pendidik dan penentu keberhasilan belajar, maka tidak berlebihan bahwa guru harus mendapat perhatian luar biasa terkait peningkatan kompetensinya secara berkesinambungan (Sumaryoto, 2017).

Pendidikan pada dasarnya merupakan suatu upaya untuk memberikan pengetahuan, wawasan, keterampilan dan keahlian tertentu kepada individu guna mengembangkan dirinya sehingga mampu menghadapi setiap perubahan yang terjadi akibat adanya kemajuan ilmu pengetahuan dan teknologi. Oleh karena itu, masalah pendidikan perlu mendapat perhatian dan penanganan yang lebih baik menyangkut berbagai masalah yang berkaitan dengan kualitas pendidikan. Hal tersebut karena pendidikan merupakan usaha atau aktivitas yang disengaja dan bertujuan yang didalamnya terlibat berbagai faktor yang saling berkaitan antara satu dengan lainnya, sehingga membentuk suatu sistem yang saling memengaruhi (Yahya, 2009).

Di samping itu, menulis merupakan budaya peradaban tertinggi untuk mencatat gagasan cemerlang para akademisi. Hal itu dapat dilakukan dalam kegiatan menulis eksposisi. Penguasaan kalimat efektif sebagai unsur bahasa ilmiah dapat meningkatkan keterampilan menulis eksposisi (Oktaria dkk., 2017). Untuk itu, pengembangan sumber daya manusia merupakan salah satu cara untuk meningkatkan kualitas manusia Indonesia seutuhnya dan untuk pelaksanaan pembangunan. Oleh karena itu, kualitas sumber daya alam tidak terlepas dari kualitas pendidikan yang terjadi pada saat ini sehingga peningkatan kualitas pendidikan harus diikuti dengan peningkatan proses pembelajaran yang terjadi di sekolah.

Pendidikan pada dasarnya merupakan suatu upaya untuk memberikan pengetahuan, wawasan, keterampilan dan keahlian tertentu kepada individu guna mengembangkan dirinya sehingga mampu menghadapi setiap perubahan yang terjadi akibat adanya kemajuan ilmu pengetahuan dan teknologi. Oleh karena itu, masalah pendidikan perlu mendapat perhatian dan penanganan yang lebih baik menyangkut berbagai masalah yang berkaitan dengan kualitas pendidikan.

Berkaitan dengan hal di atas, salah satu mutu pendidikan di Indonesia dapat ditunjukkan oleh hasil belajar yang dicapai oleh siswa. Namun, kenyataannya dalam belajar mengajar sesuai dengan tujuan tidaklah mudah. Dalam kegiatan belajar mengajar di sekolah sering dijumpai beberapa masalah, di antaranya masih sering dijumpai siswa yang mempunyai nilai rendah dalam sejumlah mata 
pelajaran, khususnya pembelajaran bahasa Indonesia. Berdasarkan pengalaman di sekolah bahwa praktik pembelajaran bahasa Indonesia di kelas lebih berpusat pada guru dan siswa lebih ditekankan pada kemampuan untuk mengingat atau menghafal sehingga kurang menekankan pada pemahaman, hal tersebut mengakibatkan pemahaman siswa dalam kegiatan pembelajaran menjadi sangat rendah dan proses pembelajaran bahasa Indonesia di kelas hanya mengikuti langkah-langkah ataupun contoh yang diberikan oleh guru saja. Dalam hal ini masalah tidak hanya dari dalam diri siswa, terdapat beberapa faktor yang juga memengaruhi hasil belajar bahasa Indonesi siswa, salah satunya adalah kecerdasan emosional. Untuk meningkatkan hasil belajar, diperlukan peran aktif dari seluruh komponen pendidikan terutama siswa yang berperan penting dalam pembelajaran serta guru sebagai fasilitator.

Penguasaan kalimat merupakan penguasaan yang penting untuk dimiliki. Penguasaan kalimat merupakan pemahaman atau kesanggupan untuk menggunakan kalimat yang menjadi salah satu standar kompetensi pembelajar. Menurut Badudu (1994) kalimat efektif ialah kalimat yang baik karena apa yang dipikirkan atau dirasakan oleh pembaca (penulis dalam bahasa tulis) dapat diterima dan dipahami oleh pendengar (pembaca dalam bahasa tulis) sama benar dengan apa yang dipikirkan atau dirasakan oleh penutur atau penulis. Selain itu, Badudu (1994) juga berpendapat bahwa "sebuah kalimat dapat efektif apabila mencapai sasaran dengan baik sebagai alat komunikasi”.

Menurut Rahim (2009), "pembinaan bahasa Indonesia sebagai sebuah proses, dilaksanakan dalam berbagai usaha seperti pengajaran bahasa Indonesia". Pengajaran bahasa Indonesia pada dasarnya harus diartikan memiliki peran (1) memperkenalkan ciri-ciri dan membangkitkan penghargaan pada bahasa Indonesia nonbaku; (2) memperkenalkan ciri-ciri fungsi berbagai varian bahasa yang ada sehingga pengajaran bahasa Indonesia lebih relevan untuk anak didik; dan (3) memandu siswa mempergunakan ciri bahasa yang tepat sesuai dengan fungsinya. Keterampilan menulis merupakan salah satu keterampilan berbahasa yang perlu dikuasai oleh siswa. Keterampilan menulis juga diperlukan agar siswa mampu menulis dengan baik dan utuh. Selain itu, kemampuan menulis bukanlah sesuatu yang datang sekaligus, melainkan dilatih secara berkesinambungan, sehingga pembelajaran menulis perlu terus diperhatikan dan ditingkatkan agar siswa memiliki dasar yang kuat tentang kemampuan kebahasan di jenjang yang lebih tinggi.

Eksposisi digunakan untuk mengusulkan sesuatu kepada pihak lain. Dengan demikian, eksposisi diproduksi dalam konteks sosial yang melatarbelakangi kegiatan-kegiatan yang dilakukan oleh manusia, baik konteks situasi maupun konteks budaya. Eksposisi merupakan pemaparan sejumlah pengetahuan atau informasi. Eksposisi tersebut memaparkan atau menerangkan suatu hal objek dengan sejelas-jelasnya, eksposisi menggunakan contoh, grafik, serta berbagai bentuk fakta dan data lainnya untuk memperjelas masalah yang dikemukakan. Tujuannya agar pembaca mendapat informasi dan pengetahuan dengan sejelasjelasnya. Selain itu, eksposisi dapat ditemukan dalam jenis karangan yang berupa resep, petunjuk penggunaan, laporan ilmiah, ataupun artikel (Kosasih, 2012).

Keterampilan menulis merupakan salah satu bentuk keterampilan berbahasa yang sangat penting bagi siswa di samping keterampilan menyimak, berbicara, dan 
membaca baik selama pendidikan maupun dalam kehidupannya nanti di masyarakat. Keberhasilan siswa dalam mengikuti kegiatan belajar mengajar di sekolah banyak ditentukan kemampuannya dalam menulis. Oleh karena itu, pembelajaran menulis mempunyai kedudukan yang sangat strategis dalam pendidikan dan pengajaran. Meskipun disadari bahwa penguasaan bahasa mutlak diperlukan dalam kehidupan modern tetapi dalam kenyataannya pengajaran keterampilan menulis kurang mendapatkan perhatian. Pelajaran mengarang sebagai salah satu aspek dalam pengajaran bahasa Indonesia kurang ditangani secara sungguh-sungguh. Pengajaran menulis sebagai bagian integral dari pengajaran bahasa Indonesia yang diberikan bertujuan agar siswa mampu menuangkan gagasannya dalam bahasa tulis dengan lancar dan tertib. Faktor lain yang mempengaruhi kemampuan siswa dalam menulis adalah kecerdasan emosional atau EQ (Emotional Quotient). Hal ini seperti ditegaskan Goleman (1999) bahwa "kecerdasan intelektual dan kecerdasan emosional merupakan faktor yang mempengaruhi keberhasilan siswa dan belajar". Menurut Dough Lennick yang dikutip Uno (2010) yang diperlukan untuk sukses dimulai dengan keterampilan intelektual, tetapi orang juga memerlukan kecakapan emosi untuk memanfaatkan potensi bakat mereka secara penuh. Salah satu penyebab tidak mencapai potensi maksimum adalah ketidakterampilan emosi. Selain itu, Safaria \& Saputra (2012) menyatakan bahwa setiap individu pasti akan menghadapi sebuah permasalahan, orang yang tidak memiliki kecerdasan emosi cenderung bersikap negatif dalam menghadapi permasalahan.

Mengingat masalah dalam mata pelajaran bahasa Indonesia sangat kompleks, maka batasan masalah yang dibahas dalam tesis ini sangat diperlukan agar tujuan dan arah yang akan disajikan jelas sehingga memudahkan penulis dalam mengakomodasi permasalahan yang muncul. Dalam hal ini yang akan dikedepankan penulis adalah pengaruh kecerdasan emosional, penguasaan struktur kalimat dan kemampuan menulis eksposisi pada siswa SMP Negeri Kelas VIII di Kabupaten Indramayu. Kecerdasan emosional sebagai variabel bebas satu $\left(\mathrm{X}_{1}\right)$, penguasaan struktur kalimat sebagai variabel bebas dua $\left(\mathrm{X}_{2}\right)$, dan kemampuan menulis eksposisi $\left(\mathrm{X}_{3}\right)$ sebagai variabel terikat. Adapun hipotesis dalam penelitian ini akan diuji menggunakan teknik regresi.

\section{METODE}

Pada penelitian ini menggunakan metode survei, yaitu dengan memberikan angket kepada responden mengenai kecerdasan emosional, penguasaan struktur kalimat dan kemampuan menulis eksposisi yang mengambil data berupa dokumen yang diberikan kepada responden. Penelitian survei mengilustrasikan prinsipprinsip penelitian korelasional dan melengkapinya dengan cara yang tepat dan efektif untuk mendeskripsikan pemikiran, pendapat, dan perasaan orang (Goleman, 2014:39). Selain itu, Sajiman (2013:31) menyatakan bahwa dalam statistika deskriptif dikemukakan cara-cara penyajian data, dengan tabel biasa, tabel kontigensi maupun distribusi frekuensi, grafik garis maupun batang, penjelasan kelompok melalui ukuran letak berupa nilai modus, median, mean, dan variasi 
kelompok melalui rentang, variansi dan simpangan baku. Adapun metode yang digunakan dalam penelitian ini adalah metode kuantitatif dengan desain penelitian berikut.

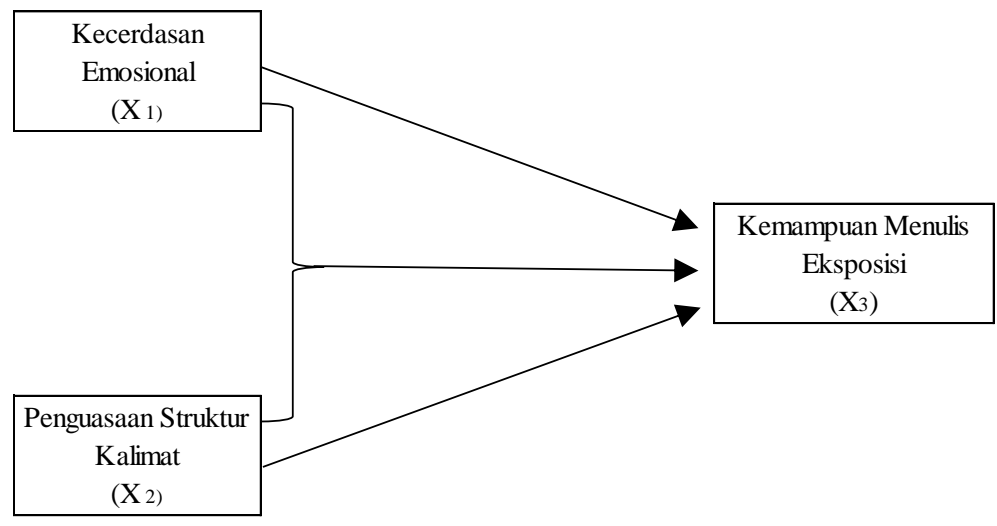

\section{Gambar 1. Paradigma Penelitian}

Hipotesis dalam penelitian ini akan diuji menggunakan teknik analisis regresi ganda dengan persyaratan data multivariate berdistribusi normal dan kecukupan sampel terpenuhi. Linearitas hubungan antara variabel bebas (kecerdasan emosional, penguasaan struktur kalimat) dan variabel terikat (kemampuan menulis eksposisi).

\section{HASIL DAN PEMBAHASAN}

\section{Hasil}

Berdasarkan hasil perhitungan statistik deskriptif data variabel penguasaan struktur kalimat, distribusi frekuensi data variabel penguasaan struktur kalimat secara lengkap dapat terlihat dalam tabel berikut.

Tabel 1. Deskripsi Hasil Penelitian

\begin{tabular}{lrrrr}
\hline & $\begin{array}{c}\text { Kecerdasan } \\
\text { Emosional }\end{array}$ & $\begin{array}{c}\text { Penguasaan } \\
\text { Struktur } \\
\text { Kalimat }\end{array}$ & $\begin{array}{c}\text { Kemampuan } \\
\text { Menulis } \\
\text { Eksposisi }\end{array}$ \\
\hline $\mathrm{N}$ & Valid & 60 & 60 & 60 \\
\cline { 2 - 5 } Mean & 0 & 0 & 0 \\
Median & 107.85 & 15.32 & 17.80 \\
Mode & 107.00 & 16.00 & 18.00 \\
Std. Deviation & 107 & 17 & 20 \\
Variance & 7.763 & 2.813 & 2.537 \\
Skewness & 60.265 & 7.915 & 6.434 \\
Std. Error of Skewness & .077 & .241 & .078 \\
& .309 & .309 & .309
\end{tabular}


Diskursus: Jurnal Pendidikan Bahasa Indonesia

Vol. 3, No. 1, April 2020, pp. 86-94

p-ISSN: 2615-4935

e-ISSN: 2615-4943

\begin{tabular}{lrrr} 
Kurtosis & -.781 & 1.024 & -.705 \\
Std. Error of Kurtosis & .608 & .608 & .608 \\
Minimum & 92 & 10 & 13 \\
Maximum & 123 & 25 & 24 \\
\hline
\end{tabular}

Pengujian hipotesis dilakukan sesuai dengan ketentuan dan dalam melakukan analisis korelasi diperoleh hasil sebagai berikut.

Tabel 2. Matriks Korelasi Antar Variabel Dalam Penelitian $(n=60)$

\begin{tabular}{|c|c|c|c|c|}
\hline \multicolumn{5}{|c|}{ Correlations } \\
\hline & & $\begin{array}{r}\text { Kecerdasan } \\
\text { Emosional }\end{array}$ & $\begin{array}{c}\text { Penguasaan } \\
\text { Struktur } \\
\text { Kalimat }\end{array}$ & $\begin{array}{c}\text { Kemampuan } \\
\text { Menulis } \\
\text { Eksposisi }\end{array}$ \\
\hline \multirow[t]{3}{*}{ Kecerdasan Emosional } & Pearson Correlation & 1 & $.499^{\prime \prime}$ & $.647^{m \prime}$ \\
\hline & Sig. (2-tailed) & & .000 & .000 \\
\hline & $N$ & 60 & 60 & 60 \\
\hline \multirow{3}{*}{$\begin{array}{l}\text { Penguasaan Struktur } \\
\text { Kalimat }\end{array}$} & Pearson Correlation & $.499^{m \prime}$ & 1 & $.731^{\mathrm{m}}$ \\
\hline & Sig. (2-tailed) & .000 & & .000 \\
\hline & $\mathrm{N}$ & 60 & 60 & 60 \\
\hline \multirow{3}{*}{$\begin{array}{l}\text { Kemampuan Menulis } \\
\text { Eksposisi }\end{array}$} & Pearson Correlation & $.647^{m}$ & $.731^{\mathrm{m}}$ & 1 \\
\hline & Sig. (2-tailed) & .000 & .000 & \\
\hline & $\mathrm{N}$ & 60 & 60 & 60 \\
\hline
\end{tabular}

**. Correlation is significant at the 0.01 level (2-tailed).

Adapun hasil koefisien regresi dan uji signifikansi secara parsial sebagai berikut.

Tabel 3. Koefisien Regresi dan Uji Signifikansi secara Parsial

\begin{tabular}{|c|c|c|c|c|c|}
\hline & Coeffic & $t^{a}$ & & & \\
\hline \multirow[b]{2}{*}{ Model } & \multicolumn{2}{|c|}{$\begin{array}{l}\text { Unstandardized } \\
\text { Coefficients }\end{array}$} & \multirow{2}{*}{$\begin{array}{c}\begin{array}{c}\text { Standardized } \\
\text { Coefficients }\end{array} \\
\text { Beta }\end{array}$} & \multirow[b]{2}{*}{ t } & \multirow[b]{2}{*}{ Sig. } \\
\hline & $\mathrm{B}$ & $\begin{array}{l}\text { Std. } \\
\text { Error }\end{array}$ & & & \\
\hline $1 \quad$ (Constant) & -2.967 & 2.825 & & -1.050 & .298 \\
\hline Kecerdasan Emosional & .123 & .030 & .376 & 4.110 & .000 \\
\hline Penguasaan Struktur Kalimat & .490 & .083 & .543 & 5.932 & .000 \\
\hline
\end{tabular}

a. Dependent Variable: Kemampuan Menulis Eksposisi

\section{Pembahasan}

Berdasarkan hasil penelitian, terlihat bahwa koefisien korelasi ganda pengaruh variabel bebas kecerdasan emosional dan penguasaan struktur kalimat

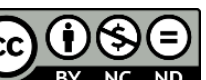

Creative Commons Attribution-NonCommercial-NoDerivatives 4.0 International License 
secara bersama-sama terhadap keterampilan menulis eksposisi adalah sebesar 0,801 . Selain itu, dari tabel di atas terlihat bahwa terdapat pengaruh yang signifikan kecerdasan emosional dan penguasaan struktur kalimat secara bersama-sama terhadap kemampuan menulis eksposisi. Dibuktikan dengan $\mathrm{F}_{\mathrm{o}}=50.862$ dan Sig. $=$ $0,000<0,05$. Sedangkan koefisien determinasinya ( $\mathrm{R}$ square) sebesar 0,641 menunjukkan bahwa besarnya kontribusi kecerdasan emosional dan penguasaan struktur kalimat secara bersama-sama terhadap kemampuan menulis eksposisi adalah sebesar 64,1\% (mayoritas), sisanya (sebesar 35,9\%) karena disebabkan faktor lainnya. Pengujian signifikansi garis regresi tersebut adalah dengan memperhatikan hasil perhitungan yang ada. Menurut ketentuan yang ada, kriteria signifikansi regresi tersebut adalah "jika Sig $<0.05$ maka $\mathrm{H}_{0}$ ditolak" atau "jika $\mathbf{F}_{\text {hitung }}>\mathbf{F}_{\text {tabel }}$ maka $\mathrm{H}_{0}$ ditolak", yang berarti bahwa koefisien regresi tersebut signifikan, dengan kata lain terdapat pengaruh yang signifikan variabel bebas $\mathrm{X}_{1}$ dan $\mathrm{X}_{2}$ terhadap variabel terikat Y. Nilai Sig adalah bilangan yang tertera pada kolom Sig. Nilai $\mathbf{F}_{\text {hitung }}$ adalah bilangan yang tertera pada kolom $\mathbf{F}$. Atau terlihat bahwa nilai Sig $=0,000$ dan $\mathbf{F}_{\text {hitung }}=50,862$ sedangkan $\mathbf{F}_{\text {tabel }}=2,76$. Karena nilai Sig $<0,05$ dan $\mathbf{F}_{\text {hitung }}>\mathbf{F}_{\text {tabel }}$ maka $\mathrm{H}_{0}$ di tolak yang berarti bahwa koefisien regresi tersebut signifikan. Kecerdasan emosional mengacu pada perasaan terhadap informasi suatu hubungan. Kemampuan menulis eksposisi memiliki peran penting dalam pembelajaran bahasa Indonesia, sebab dengan sering menggali pengetahuan dan berlatih, bahkan ada kegiatan belajar-mengajar di sekolah hampir tidak bisa lepas dengan kegiatan menulis, padahal semakin sering kegiatan menulis dilaksanakan maka semakin tinggi pula tingkat kemampuan siswa dalam berkarya melalui media tulisan. Dengan adanya penguasaan struktur kalimat dalam diri seseorang maka dapat mengungkapkan isi yang ada dalam pikiran dalam simbolsimbol bahasa atau dapat merangkai kata yang mudah untuk dipahami pembacanya. Temuan ini menunjukkan bahwa salah satu faktor intern yang cukup berperan dalam meningkatkan kemampuan menulis eksposisi adalah kecerdasan emosional dan penguasaan struktur kalimat. Selain itu, menulis eksposisi adalah tulisan yang memberikan informasi mengenai mengapa dan bagaimana, menjelaskan sebuah proses, atau menjelaskan sebuah konsep, sehingga dengan tulisan eksposisi siswa diharapkan dapat mengetahui bagaimana dan mengapa sesuatu bisa terjadi. Berdasarkan deskripsi data hasil penelitian dan teori tersebut maka peneliti berkesimpulan bahwa terdapat pengaruh yang signifikan kecerdasan emosional dan penguasaan struktur kalimat secara bersama-sama terhadap kemampuan menulis eksposisi.

Berdasarkan hasil penelitian terlihat bahwa nilai Sig $=0,000$ dan thitung $=$ $4,110>2,000$. Karena nilai $\mathrm{Sig}<0,05$ dan $\mathrm{t}_{\text {hitung }}>\mathrm{t}_{\text {tabel }}$ maka $\mathrm{H}_{0}$ di tolak yang berarti terdapat pengaruh yang signifikan kecerdasan emosional terhadap variabel terikat kemampuan menulis eksposisi. Banyaknya informasi ilmu pengetahuan maupun 


\section{Diskursus: Jurnal Pendidikan Bahasa Indonesia}

Vol. 3, No. 1, April 2020, pp. 86-94

p-ISSN: 2615-4935

e-ISSN: 2615-4943

berita kehidupan di tengah masyarakat yang nyata telah disampaikan oleh media cetak, maka dengan menulis siswa dapat berlatih secara langsung maupun tidak langsung dalam mengungkapkan fakta nyata. Selain itu siswa dapat menulis sebagai suatu kegiatan yang menyenangkan, karena siswa bisa menelusuri wilayah mana saja, dan siswa dapat menulis sebagai suatu kegiatan yang menyenangkan karena siswa inginkan sebagai objek dari karyanya tersebut. Menulis adalah suatu kegiatan aktif yang dengan sadar dilakukan secara bertanggung jawab sehingga dapat melatih kecerdasan siswa. Untuk mengungkapkan isi sebuah paparan sangat diperlukan pemahaman yang mendalam pada sebuah topik pembicaraan, baik yang tersurat maupun yang tersirat. Berdasarkan deskripsi data hasil penelitian dan teori tersebut maka peneliti berkesimpulan bahwa terdapat pengaruh yang signifikan kecerdasan emosional terhadap kemampuan menulis eksposisi.

Temuan penelitian menunjukkan terdapat pengaruh yang signifikan penguasaan struktur kalimat terhadap kemampuan menulis eksposisi, hal tersebut terlihat dari terlihat nilai Sig $=0,000$ dan $t_{\text {hitung }}=5,932>2,000$ sedangkan $t_{\text {tabel }}=$ 2,021 .

Kaitannya dengan kemampuan menulis eksposisi, seperti siswa kurang dapat menggunakan kalimat secara baik dan benar terutama dalam berkomunikasi lisan maupun tulisan, maka perlu sekali orang tua dan guru memberikan dorongan dan bimbingan yang benar-benar terhadap minat siswa dalam belajar bahasa dan sastra Indonesia. Selain itu, kaitannya dengan kemampuan menulis eksposisi, seperti siswa kurang dapat menggunakan kalimat secara baik dan benar terutama dalam berkomunikasi lisan maupun tulisan, maka perlu sekali orang tua dan guru memberikan dorongan dan bimbingan.

Upaya-upaya yang dapat dilakukan untuk merangsang dan meningkatkan kemampuan menulis eksposisi yang dapat diterapkan para guru diantaranya dengan mengukur tingkat kecerdasan emosional dan penguasaan struktur kalimat dalam mata pelajaran bahasa Indonesia, dan juga bagi manajemen satuan pendidikan agar menyiapkan sarana untuk memfasilitasi para siswa dalam melaksanakan kegiatan pembelajaran dan melakukan tindak lanjut untuk menangani siswa yang belum tuntas atau belum mencapai mastery berdasarkan hasil penelitian.

Dengan dilakukannya upaya-upaya tersebut diharapkan para siswa akan lebih memahami akan pentingnya keterkaitan antara kecerdasan emosional, penguasaan struktur kalimat dan kemampuan menulis eksposisi. Selain itu, juga diharapkan para guru akan termotivasi dan terbiasa melaksanakan kegiatan pembelajaran yang variatif untuk mengevaluasi efektivitas pembelajaran. Pada akhirnya, diharapkan agar mutu hasil belajar bahasa Indonesia siswa menjadi meningkat dan sesuai dengan yang diharapkan. 


\section{SIMPULAN}

Berdasarkan hasil analisis yang telah dilakukan, diperoleh simpulan bahwa (1) terdapat pengaruh yang signifikan kecerdasan emosional dan penguasaan struktur kalimat secara bersama-sama terhadap kemampuan menulis eksposisi; (2) terdapat pengaruh yang signifikan kecerdasan emosional terhadap kemampuan menulis eksposisi; (3) terdapat pengaruh yang signifikan penguasaan struktur kalimat terhadap kemampuan menulis eksposisi.

Hasil penelitian yang telah diuraikan, ditemukan bahwa kecerdasan emosional dan penguasaan struktur kalimat merupakan faktor yang sangat penting dalam meningkatkan kemampuan menulis eksposisi. Berdasarkan temuan ini, maka dalam rangka meningkatkan kemampuan menulis eksposisi dapat dilakukan dengan cara menumbuhkan kecerdasan emosional dan penguasaan struktur kalimat.

\section{DAFTAR PUSTAKA}

Badudu, J. S. (1994). Kamus kata-kata serapan asing dalam bahasa Indonesia. Jakarta: Kompas.

Goleman, D. (1999). Working with emotional intelligence, Diterjemahkan oleh Alex Tri Kuncoro Widodo: Kecerdasan Emosional untuk Mencapai Puncak Karir. Jakarta: Gramedia Pustaka Utama.

Kosasih, E. (2012). Dasar-dasar keterampilan menulis. Bandung: Yrama Widya.

Oktaria, D., Andayani, NFN., \& Saddhono, K. (2017). Penguasaan kalimat efektif sebagai kunci peningkatan keterampilan menulis eksposisi. Jurnal Metalingua, 15(2), 165-177. http://metalingua.kemdikbud.go.id /jurnal/index.php/metalingua/article/view/63/68

Rahim, R. (2009). Bina bahasa. Makassar: Unismuh Makassar.

Safaria, T., \& Saputra, N.E. (2012). Manajemen emosi. Jakarta: Bumi Aksara.

Sajiman, S. U. (2013). Aplikasi statistika dalam penelitian. Edisi Revisi. Jakarta: Change Publication.

Sumaryoto. (2017). Keynote Speech - Menjadi guru pembelajar. Prosiding Diskusi Panel Nasional Pendidikan, 1(1), 1-8. https://journal.lppmunindra. ac.id/index.php/repository/article/view/1679/1297

Uno, H. B. (2010). Orientasi baru dalam psikologi pembelajaran. Jakarta: Bumi Aksara.

Yahya, M. (2009). Pengantar pendidikan. Bandung: Prospect. 